\title{
Muramyl Dipeptide
}

National Cancer Institute

\section{Source}

National Cancer Institute. Muramyl Dipeptide. NCI Thesaurus. Code C201.

A naturally occurring component of bacterial cell walls that has the capacity to activate macrophages. 